\title{
Age, Blood Pressure, Body Mass Index and Fasting Blood Glucose Level of DM Patients at dr Rasidin Hospital, West Sumatera
}

\author{
Hafifatul Auliya Rahmy ${ }^{1 *}$, Rahmi Putri ${ }^{1}$, Sisri Eka Putri ${ }^{1}$, Nur Inggrid Saumi ${ }^{1}$ \\ $\left\{\right.$ hafifatul@ph.unand.ac.id $\left.{ }^{1}\right\}$
}

Department of Nutrition, Faculty of Public Health, Andalas University, Indonesia ${ }^{1}$

\begin{abstract}
Type II Diabetes Mellitus (DM) is a metabolic disorder that is currently a major health problem in Indonesia and one of the degenerative diseases which high morbidity at dr Rasidin Hospital. This study aimed to determine the correlation between age, blood pressure, and body mass index with fasting blood glucose. This study was a quantitative research with cross-sectional design. This study involved 88 respondents. Fasting blood glucose using spectrophotometers method collected by medical analysts of a laboratory of dr Rasidin Hospital. Statistical calculation was done using simple linear regression. The result showed the average of blood glucose levels were $177.31 \mathrm{mg} / \mathrm{dl}$. There was a significant positive correlation between age, blood pressure, body mass index and fasting blood glucose $(\mathrm{P}<0.001)$. Food habits and regular physical activity may prevent high blood pressure and high body mass index. It may help in prompt treatment or future preventive complications.
\end{abstract}

Keywords: Age, Blood Glucose Level, Blood Pressure, BMI, Type II Diabetes Mellitus,

\section{Introduction}

Diabetes Mellitus is a group of metabolic diseases. That characterized by hyperglycemia resulting from defects in insulin secretion, insulin action, or both. The chronic hyperglycemia of diabetes is associated with long-term damage, dysfunction, and failure of different organs, especially the eyes, kidneys, nerves, heart, and blood vessels. Several pathogenic processes are involved in the development of diabetes. These range from autoimmune destruction of the $\beta$ cells of the pancreas with consequent insulin deficiency to abnormalities that result in resistance to insulin action. The basis of the abnormalities in carbohydrate, fat, and protein metabolism in diabetes is deficient action of insulin on target tissues. Deficient insulin action results from inadequate insulin secretion and/or diminished tissue responses to insulin at one or more points in the complex pathways of hormone action. Impairment of insulin secretion and defects in insulin action frequently coexist in the same patient, and it is often unclear which abnormality, if either alone, is the primary cause of the hyperglycemia [1].

The prevalence of diabetes mellitus in Indonesia is always increasing. The prevalence of people with Diabetes Mellitus with glucose blood level $\geq 126 \mathrm{mg} / \mathrm{dl}$ in Indonesia tends to increase, from $0.7 \%$ in 2007 to $1.5 \%$ in 2013 and increased again to $2 \%$ in 2018 . West Sumatra Province is one of the provinces that has also increased. The prevalence of diabetes mellitus in West Sumatera Province increased from $0.7 \%$ in 2007 to $1.3 \%$ in 2013 and 
increased again to $1.6 \%$ in 2018. Based on the DM Disease Report of the Health Office of West Sumatra Province in 2018, the number of DM sufferers was 33,625 people [2-5].

Type Two Diabetes Mellitus factors can be irreversible, such as age, genetic, race, and ethnicity or revisable such as diet, physical activity, and smoking. The world prevalence of diabetes among adults (aged 20-79 years) will be 6.4\%, affecting 285 million adults, in 2010, and will increase to $7.7 \%$, and 439 million adults by 2030 . Between 2010 and 2030, there will be a $69 \%$ increase in numbers of adults with diabetes in developing countries and a $20 \%$ increase in developed countries [6]. More than $90 \%-95 \%$ of diabetes patients belong to this type, and most of these patients are adults. The number of youth (less than 20 years) with type 2 diabetes in the United States in the year 2009 was 0.46 in 1000 and accounted for approximately $20 \%$ of type 2 diabetes in youth [7].

Blood Pressure also a risk factor of diabetes mellitus. Many studies have reported the relation between hypertension and DM. People with high blood pressure were found to have around a $50 \%$ increased risk of developing type 2 diabetes. Prehypertension, as well as hypertension, were strongly and independently associated with type 2 diabetes. Prehypertension is associated with increased cardiovascular risk and insulin resistance [8-9].

Age is one of the most important risk factors for type 2 diabetes Diabetes is progressive, and glucose levels are known to increase with age. However, there is also evidence for differences in the pathophysiology of type 2 diabetes in older compared with younger individuals [10].

Diabetes is a disease of the third highest in the dr Rasidin hospital. Based on data obtained from the hospital is going on the increase in the number of patient visits. The number of patient visits is as much as 56.367 in 2016, increased significantly to 62.944 years 2017 , and increased 69.089 years 2018. So that research aims to understand relations age, blood pressure, body mass index in blood sugar patients diabetes mellitus in the dr Rasidin hospital.

\section{Method}

This study was a quantitative study with a crossectional approach. The study was conducted in Dr. Rasidin hospital, west Sumatera, in June-Agustus 2019. It involved 88 people with DM who participated in using purposive sampling.

Data collection was done through questionnaires and direct interviews with respondents. The questionnaire was developed by researchers to obtain information about the characteristics of respondents (gender, age, education level, profession, food habits), and the main independent variables were age, blood pressure (BP), body mass index. Fasting blood glucose using spectrophotometers method collected by medical analysts of a laboratory of $\mathrm{dr}$ Rasidin Hospital. Univariate analysis and bivariate are used to figure out the main characteristics and independent variables. The analysis was done using simple linear regression.

\section{Result}

Table 1. shows an overview of the blood sugar levels of respondents based on gender, age, education level. Most of the respondents were uncontrolled blood sugar level (71.6\%), 
women $(68.2 \%)$ and age $>45$ years $(93,2 \%)$. Average of systolic BP $130.34 \mathrm{mmHg}$, diastolic BP $75.03 \mathrm{mmHg}$, and BMI $24.5 \mathrm{~kg} / \mathrm{m}^{2}$.

Tabel 1. Overview of Blood Glucose Levels, Characteristics (Gender, Age, Education Level) and Blood Pressure of Respondents

\begin{tabular}{|c|c|c|c|}
\hline Variable & $\mathbf{N}$ & $\%$ & Average \pm SD \\
\hline Blood Glucose Levels (mg/dl) & & & $171.31 \pm 75.6$ \\
\hline Uncontrolled & 63 & 71.6 & \\
\hline Controlled & 25 & 28.4 & \\
\hline \multicolumn{4}{|l|}{ Gender } \\
\hline Female & 28 & 31.8 & \\
\hline Male & 60 & 68.2 & \\
\hline Age of Respondents (years) & & & $55.5 \pm 8.76$ \\
\hline$\geq 45$ years old & 6 & 6.8 & \\
\hline$<45$ years old & 82 & 93.2 & \\
\hline \multicolumn{4}{|l|}{ Educational Level } \\
\hline Uneducated & 5 & 5.7 & \\
\hline Elementary School Graduates & 10 & 11.4 & \\
\hline Junior High School Graduates & 28 & 31.8 & \\
\hline High School Graduates & 27 & 30.7 & \\
\hline Higher Education Graduates & 18 & 20.5 & \\
\hline Systolic Blood Pressure (mmHg) & & & $130.34 \pm 20.3$ \\
\hline Hypertension & 30 & 34.1 & \\
\hline Elevated & 31 & 35.2 & \\
\hline Normal & 27 & 30.6 & \\
\hline Diastolic Blood Pressure (mmHg) & & & $75.03 \pm 10.2$ \\
\hline Hypertension & 3 & 3.4 & \\
\hline Elevated & 32 & 36.4 & \\
\hline Normal & 53 & 60.2 & \\
\hline Body Mass Index $\left(\mathrm{kg} / \mathrm{m}^{2}\right)$ & & & $24.5 \pm 3.7$ \\
\hline Obesity & 39 & 44.3 & \\
\hline Overweight & 22 & 25 & \\
\hline Normal & 21 & 23.9 & \\
\hline Underweight & 6 & 6.8 & \\
\hline
\end{tabular}

Table 2 is the result of the food habits of the respondent. The results of shows $39.8 \%$ respondents who had consumption sweet food less than three times per weeks, $47.7 \%$ respondents who had consumption sweet drinks less than three times per weeks, $61.4 \%$ respondents who had consumption salty food less than three times per weeks, $30.7 \%$ respondents who had consumption food sources of fat, cholesterol, and fried foods once time per days, $60.2 \%$ respondents who had consumption burnt food less than three times per 
weeks, $81.8 \%$ never consumption preserved food, $95.5 \%$ never consumption energy drinks and $84.1 \%$ never consumption soft drinks.

Tabel 2. Overview of food habits of respondent

\begin{tabular}{lcccccc}
\hline \multicolumn{1}{c}{ Variables } & $\begin{array}{c}>1 \text { times } \\
\text { per day }\end{array}$ & $\begin{array}{c}\mathbf{1} \text { time } \\
\text { per day }\end{array}$ & $\begin{array}{c}\text { 3-6 times } \\
\text { per weeks }\end{array}$ & $\begin{array}{c}\mathbf{1 - 2} \text { times per } \\
\text { weeks }\end{array}$ & $\begin{array}{c}<3 \text { times } \\
\text { per weeks }\end{array}$ & Never \\
\hline Sweet food & $3.4 \%$ & $9.1 \%$ & $18.2 \%$ & $25 \%$ & $39.8 \%$ & $4.5 \%$ \\
Sweet drinks & $2.3 \%$ & $11.4 \%$ & $11.4 \%$ & $19.3 \%$ & $47.7 \%$ & $8 \%$ \\
Salty food & $3.4 \%$ & $2.3 \%$ & $1.1 \%$ & $9.1 \%$ & $61.4 \%$ & $22.7 \%$ \\
$\begin{array}{l}\text { Food sources of } \\
\text { fat, cholesterol }\end{array}$ & $19.3 \%$ & $30.7 \%$ & $23.9 \%$ & $13.6 \%$ & $12.5 \%$ & $0 \%$ \\
and fried foods & & & & & & \\
Burnt food & $0 \%$ & $1.1 \%$ & $3.4 \%$ & $9.1 \%$ & $60.2 \%$ & $26.1 \%$ \\
Preserved food & 0 & 0 & 0 & 0 & $18.2 \%$ & $81.8 \%$ \\
soft drinks & 0 & 0 & $3.4 \%$ & 0 & $14.8 \%$ & $84.1 \%$ \\
Energy drinks & & & $1.1 \%$ & & $3.4 \%$ & $95.5 \%$ \\
\hline
\end{tabular}

Furthermore, Tabel 3 is the results of the simple linear regression analysis showed there was a correlation between age, blood pressure, and body mass index with blood sugar levels.

Table 3. Linear Regression analysis

\begin{tabular}{lcc}
\hline Variable & r (Pearson) & P-value \\
\hline Age & 0.010 & 0.000 \\
Systolic BP & 0.486 & 0.000 \\
Diastolic BP & 0.298 & 0.005 \\
BMI & 0.134 & 0.044 \\
\hline
\end{tabular}

That the blood glucose level of the respondents was influenced by age, blood pressure and BMI (p-value $<0.05$ )

\section{Discussion}

\subsection{Blood glucose levels}

Your blood sugar is an essential measure of your health. Too much sugar in the blood is the common factor between all types of diabetes. Many foods break down into blood sugar, which is used for energy to fuel our brain, heart, and muscles. Blood sugar either comes from the food we eat or is made by the liver. It's usually found in two locations; in the bloodstream as it is carried to all of our organs and cells, and inside the cells where it is changed into energy. Controlling good and optimal blood glucose levels is needed to be able to prevent chronic complications [11]. The results of the examination of blood sugar levels found that from 45 respondents, there were $71,6 \%$ who had uncontrolled blood sugar levels and the 
average of blood glucose levels is $171.31 \pm 75.6 \mathrm{mg} / \mathrm{dl}$. Similar to Setyaningrum et al., research who gets an average level of GDP of type II DM in Semarang Tugurejo Hospital is 186.81 $\mathrm{mg} / \mathrm{dl}$. The results are higher than Fahmiyah from 50 patients in the Diabetes Policlinic of Dr. Soetomo Hospital. There were $66 \%$ who had uncontrolled blood glucose levels and $34 \%$ who had controlled blood sugar levels $[12,13]$.

\subsection{Age, Blood Pressure and BMI with Blood Glucose Level}

The results showed a positive correlation between age and blood glucose levels with a pvalue $<0.05$. As we get older, it also increases the risk of developing DM. Many people with type 2 diabetes get older as they age because it is due to the reduced number of productive $\beta$ cells as we get older. Humans generally experience a decrease in physiological function after the age of 40 years. DM often appears after a person enters a vulnerable age, especially after the age of 45 years in those who are overweight, so the body is no longer sensitive to insulin. Existing theories say that a person $\geq 45$ years has an increased risk of developing DM and glucose intolerance caused by degenerative factors, namely decreased body function, specifically the ability of $\beta$ cells to produce insulin in metabolizing glucose [14]. Research in Betteng in 2014 was conducted on ten women of childbearing age at Puskesmas Wawonasa. The youngest was found in the eighth informant, while the oldest was found in the third informant. In this study, the identity of the informants obtained the youngest age of the informant is 36 years, and the oldest age is 61 years [15]. Increasing age and obesity are the main risk factors for increasing blood sugar levels apart from genetics. According to AlGoblan, one of the risk factors for diabetes mellitus is obesity. The accumulation of excess body fat can cause the response of beta cells to blood glucose to be reduced. In addition, insulin receptors on target cells become resistant, and the amount is reduced so that insulin in the blood cannot be utilized. In people who are overweight, leptin levels in the body will increase. Leptin is an adipokine that has a role in maintaining energy homeostasis in the body. This increased leptin will then inhibit substrate I receptor insulin phosphorization will cause an increase in blood sugar levels due to inhibition of glucose uptake [16].

In this study, there was a positive relationship between systolic blood pressure and diastole with glucose levels in the blood. Hypertension and DM are two diseases that have a very close relationship. These two conditions are problems that require proper and careful management. Hypertension not only causes heart attacks, heart failure, and strokes but also diabetes in new patients. According to The National Cholesterol Education Program, Adult Treatment Panel (NCEP / ATP) III and International Diabetes Federation (IDF), the metabolic syndrome occurs when there are at least three of the following five medical conditions. It includes central obesity, high blood pressure, increased fasting plasma glucose, triglyceride levels high serum levels, and low levels of high-density lipoprotein (HDL). Among the metabolic diseases, the most common are hypertension and diabetes mellitus, the prevalence of which increases with age. Hypertension is a major risk factor for cardiovascular disease, which is known to be the number one cause of death in Indonesia. People with metabolic syndrome have a high possibility of cardiovascular diseases such as coronary heart disease and stroke.8 Increased visceral fat at the start of the pathophysiology of metabolic syndrome triggers elevated levels of plasma fat and production of inflammatory cytokines. This increase in cytokine products can interfere with the interaction of insulin with its receptors, which can cause insulin resistance with manifestations of diabetes mellitus [9],[17]. 
In this study, there is a positive correlation between body mass index with blood glucose levels and the strength of a weak relationship. Increased adipose tissue also increases the number of immune cells that play a role in inflammation. Chronic inflammation contributes to an increased risk of hypertension and diabetes. The causes of metabolic syndrome are very complex, including genetic and environmental factors. Poor environmental factors can cause metabolic syndrome. Low physical activity, sleep disturbance, postmenopausal conditions in women, smoking, and high-carbohydrate diets are risk factors for metabolic syndrome. In addition, metabolic syndrome mostly affects older patients, who are obese, have high levels of insulin resistance, and often experience stress. Someone with excess body weight (BB) with a Body Mass Index (BMI) $>25$, which means they are classified as obese, are more at risk of developing diabetes. BB excess of $20 \%$ increases the risk doubled. Obesity can cause insulin resistance. There are at least two different mechanisms linking obesity with insulin resistance, namely through increased production of cytokinins, including tumor necrosis factor- $\alpha$, resistin, and retinol-binding protein 4 , as well as through mitochondrial dysfunction. Increased production of these cytokines contributes to insulin resistance and decreased adiponectin. Mitochondrial dysfunction can reduce insulin sensitivity to glucose, resulting in high blood glucose levels $[18,19]$.

\section{Conclusion}

The average blood sugar level of the patient is $171.31 \mathrm{mg} / \mathrm{dl}$, age 55.5 years, body weight $59.7 \mathrm{~kg}$, systolic blood pressure 130.34 , diastolic blood pressure 75.03 , and body mass index $24.5 \mathrm{~kg} / \mathrm{m} 2$. There is a positive correlation between age, blood pressure, and body mass index with blood sugar levels with a p-value $<0.05$. Uncontrolled blood sugar levels in DM patients can be prevented by avoiding eating $3 \mathrm{~J}$ and do regular physical activity for at least 30 minutes every day. They also need to control blood pressure by using balanced nutrition, limiting salt consumption, preservative foods. And applying the slogan "CERDIK" namely periodic health checks, get rid of cigarettes, exercise diligently, balanced diet and manage stress

\section{References}

[1]. American Diabetes Association. Standards of Medical Care in Diabetes. Diabetes Care. 2009:32.

[2]. Kementrian Kesehatan RI. In: Riset Kesehatan Dasar, editor. Jakarta: Badan Penelitian dan Pengembangan Kesehatan; 2007.

[3]. Kementrian Kesehatan RI. In: Riset Kesehatan Dasar, editor. Jakarta: Badan Penelitian dan Pengembangan Kesehatan; 2013.

[4]. Kementrian Kesehatan RI. In: Riset Kesehatan Dasar, editor. Jakarta: Badan Penelitian dan Pengembangan Kesehatan; 2018.

[5]. Dinas Kesehatan. Laporan Penyakit DM. In: Dinas Kesehatan Provinsi Sumatera Barat, editor. Padang.2018

[6]. Shaw Je, Sicree RA, Zimmet PZ. Global Estimates Of The Prevalence Of Diabetes For 2010 And 2030. Diabetes Research and Clinical Practice. 2010;87:4-14.

[7]. Kharroubi AT, Darwish HM. Diabetes Mellitus: The Epidemic of The Century. World Journal of Diabetes. 2015;6(6):850-67. 
[8]. Min-Ju Kim, et al. Hypertension Is An Independent Risk Factor For Type 2 Diabetes: The Korean Genome And Epidemiology Study. Hypertension Research. 2015;38:783-9.

[9]. Yaogai Lv, et al. Association of Blood Pressure with Fasting Blood Glucose Levels in Northeast China: A Cross-Sectional Study. Scientific Reports. 2018;8:7917.

[10]. Elizabeth Selvin, and Christina M. Parrinello. Age-Related Differences In Glycaemic Control In Diabetes. Diabetologia. 2013;56(12).

[11]. Soewondo P. Pemantauan Pengendalian Diabetes Melitus Jakarta: Balai Penerbit FK UI; 2005.

[12]. Setyaningrum DE, Sugiyanto Z. Faktor Risiko yang Berhubungan Dengan Kejadian Diabetes Melitus Tipe II Pada Usia Kurang Dari 45 Tahun Di RSUD Tugurejo Semarang. Jurnal Kesehatan Masyarakat. 2015;14(2).

[13]. Indah Fahmiyah, I Nyoman Latra. Faktor yang Memengaruhi Kadar Gula Darah Puasa Pasien Diabetes Mellitus Tipe 2 di Poli Diabetes RSUD Dr. Soetomo Surabaya Menggunakan Regresi Probit Biner Jurnal Sains Dan Seni ITS. 2016;5(2): 2337-3520.

[14]. Pearl G. Lee, and Jeffrey B. Halter. The Pathophysiology of Hyperglycemia in Older Adults: Clinical Considerations. Diabetes Care. 2017;40(4):444-52.

[15]. Richardo Betteng. Analisis Faktor Resiko Penyebab Terjadinya Diabetes Melitus Tipe 2 Pada Wanita Usia Produktif Dipuskesmas Wawonasa. eBiomedik. 2014;2(3).

[16]. Abdullah S Al-Goblan, Mohammed A Al-Alfi, and Muhammad Z Khan. Mechanism Linking Diabetes Mellitus And Obesity. Diabetes Metab Syndr Obes. 2014;7:587-91.

[17]. Abbas Rezaianzadeh, Seyedeh-Mahdieh Namayandeh, and Seyed-Mahmood Sadr. National Cholesterol Education Program Adult Treatment Panel III Versus International Diabetic Federation Definition of Metabolic Syndrome, Which One is Associated with Diabetes Mellitus and Coronary Artery Disease? International Journal of Preventive Medicine. 2012;3(8):552-8.

[18]. Shilpa N. Bhupathiraju, and Frank B. Hu. 2016. Circulation Research. Epidemiology of Obesity and Diabetes and Their Cardiovascular Complications;118(11):1723-35.

[19]. Neelam Agrawall, et al. Correlation between Body Mass Index and Blood Glucose Levels in Jharkhand Population. International Journal of Contemporary Medical Research. 2017;4(8):1633-6. 